\title{
Annual Report for 1969
}

Membership of the Society continued to increase at a satisfactory rate, standing at 2,870 at the end of the year. 323 new ordinary members were recruited during the year; balanced by 98 resignations and deletions and 29 deaths, this yielded a net increase in ordinary membership of 196 , compared with $\mathrm{II}_{7}$ in 1968 . In addition, as a result of the decision not to allow subscriptions to ORYX at a cheaper rate, I8I subscribers to ORYX were elected as ordinary members. (N.B. Individual copies of ORYX but not regular subscriptions may still be purchased by non-members). It is hoped that the publicity attendant on European Conservation Year 1970 will result in a substantial inflow of new members despite the increases in life and ordinary subscriptions which were agreed at the annual general meeting of 1969.

\section{The Revolving Fund}

The Revolving Fund maintained by the Society jointly with the World Wildlife Fund (International) continued to be the Society's most important means of directly aiding urgent conservation projects. The totals given below do not necessarily agree with those in the Account on p. 276, because, as mentioned last year, some sums, on being repaid by WWF, are held by them in Zürich and reallocated direct from there in order to save needless exchange transactions. At December 3I, I969, WWF held a balance of $£ 25 \mathrm{I}$ in Zürich on behalf of the Fund.

The following projects were aided during the year:

Somali Wild Ass Project, Ethiopia

Tamaraw Project, equipment, Philippines

Survey of Tortoise Stocks, Morocco (Mr Lambert)

Jordan International Biological Station, Azraq

Brown Bear, Abruzzo National Park, Italy

Kouprey Survey, Cambodia (Prof Pfeffer)

Madagascar Conference (Dr Petter)

Great Abbai Expedition, Ethiopia

Forests of S W Ethiopia (L. H. Brown)

$£ 1000$
658
650
500
495
333
300
100
66

All these except the Somali Wild Ass had been drawn on by the end of the year. The payment for the Pakistan Land Rover ( $£_{1}$ I IOO), agreed in 1968, was also made in 1969. Assistance was therefore rendered in eight different countries in Africa, Asia and Europe, and directly to five endangered species, two of them (kouprey, tamaraw) among the most gravely endangered large mammals in the world today.

A special grant of $f_{\mathrm{I}} \mathrm{i} 2 \mathrm{I}$ was made to the Uganda National Parks for the printing of information leaflets to be handed out to all visitors on the launch trips up the Nile to the Murchison Falls, explaining why it is important that launches should keep away from the crocodiles' nesting grounds (see ORYX, December, p. 153). In addition two ordinary grants were made to $\mathrm{Dr} H$. R. Bustard, $£ 260$ to enable him to promote turtle conservation in Fiji, and $£ 50$ to enable him to visit Round Island, off Mauritius, to collect a small stock of the day gecko 


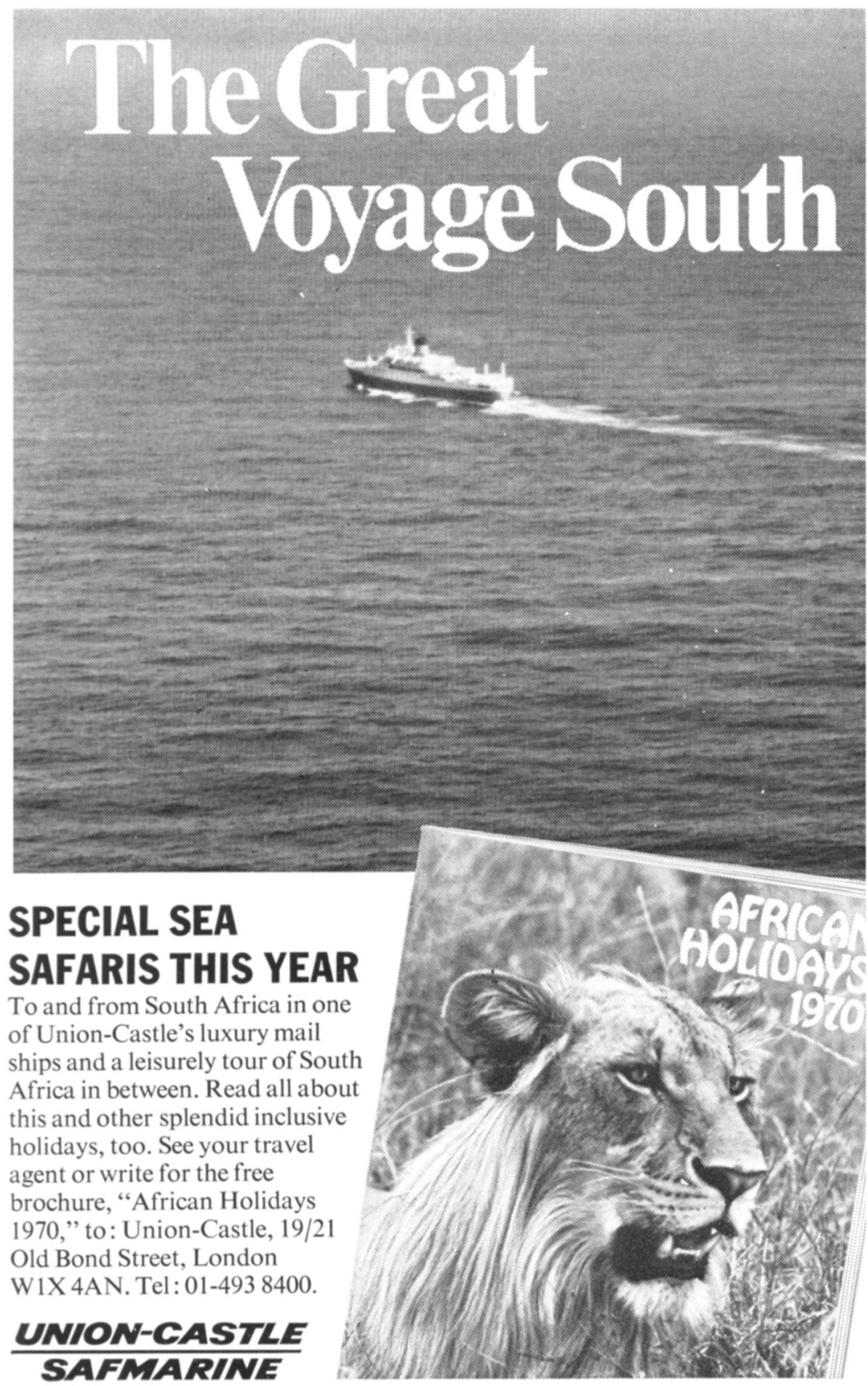




\section{Private Lives}

\section{Edited by JEFFERY BOSWALL}

\section{Introduced by Sir JULIAN HUXLEY}

The emperor penguin, red fox, Atlantic grey seal, great crested grebe, Siamese fighting fish, and kingfisher are some of the subjects included in this beautifully illustrated book of specialist natural history studies, adapted from the BBC tv series Look and Private Lives.

Thirteen different species of wild animals and birds are each followed throughout a full year of their life cycles, and their behaviour patterns are examined with the help of drawings, diagrams, maps, graphs and over 150 colour and black and white photographs.

\section{$35 s$ \\ A BBC Publication}

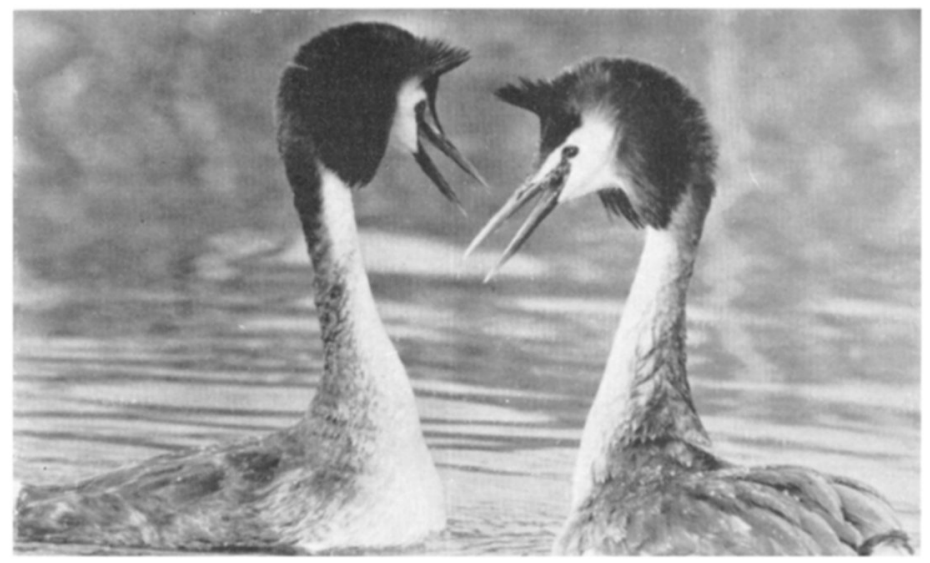


Phelsuma guentheri, a Red Data Book reptile, in order to establish a breeding stock in captivity. Earmarked grants totalling £Ioso for three projects of the East African Wildlife Society-Animal Rescue Fund, Anti-Poaching Unit and Roan Antelope Fund-were passed on.

\section{Legacies and Donations}

A legacy of $£_{1} 1000$ was received from the estate of the late Miss Marianne Fayrer Clark. Generous donations from many members included the following: Ioo guineas from Messrs $M . K$. Kendall Ltd., $f_{1}, 00$ from Mr. Ernest Kleinwort, $£ 50$ from Mr. Llewellyn-Taylour for otter conservation, an anonymous $£ 50$, and a further instalment of royalties from Mrs. Spearman's Animal Anthology. Mrs. J. E. Jessup kindly organised a jumble sale on our behalf, which realised $f$ ror, and the usual Marley Manor gymkhana brought in $£ 32$. For all these we are most grateful.

\section{The Society's Wildlife Tours}

Oryx Tour No. 7 was again to India in February, led by Mr J. C. Daniel, Curator of the Bombay Natural History Society. Places visited included the Gir Forest in Gujarat for the Indian lion, Kanha National Park and Periyar Sanctuary in South India, and the Ghana Bird Sanctuary and Sariska Reserve in Rajasthan. The Hon. Secretary and Editor visited Uganda and Ethiopia in February to prospect the route for the Society's very successful tour to those countries in February 1970. (See page 218.)

\section{International Meetings}

The Hon. Secretary and Editor represented the Society at the Ioth General Assembly of IUCN at New Delhi, India, in November/ December, and attended three meetings of the Survival Service Commission, at Morges, Switzerland, in April, Bonn, Germany, in July, and New Delhi, in November.

\section{Representation on Other Bodies}

Representation of the Society on other bodies continued to be as set out in the 1968 Annual Report, except that the Society joined the Biological Council during the year, Major W. N. Scott acting as our representative, and the Hon. Secretary was the Society's observer at the meeting of the International Whaling Commission in London in June. Under the new arrangements for financing the Council for Nature, the national representative body for natural history and conservation bodies in Britain, the Society, which has two representatives on the Council, subscribed $£ 250$. Two other societies subscribed $£_{500}$, two $£_{100}$, and the rest smaller sums. The annual subscription to the International Council for Bird Preservation continued at $£ 25$.

\section{Arabian Oryx Herd}

Three calves were born to the World Herd of Arabian Oryx during the year, but one died, leaving the total number at 20 at the end of the year. The Society's share was Io (6 males and 4 females). 


\section{Meetings of the Society}

At the Annual General Meeting on June II, Eugen Schuhmacher's colour film, 'The Last of the Wild' was shown. There were also four ordinary meetings. On March 27, at a special memorial meeting for the late E. P. Gee, John Willett showed his film of Indian wildlife. On September 18, at the annual reunion meeting for participants in the Society's African and Indian tours, Guy Mountfort spoke on conservation problems in Pakistan and showed a new film of Pakistan wildlife. On November 6, Peter Scott spoke on conservation in Alaska, with slides, and on November 26 Lt. Col. and Mrs. Boyle spoke on wildlife and conservation in New Zealand, with slides. The meetings on March 27, June II and November 6 were followed by wine and cheese parties which have proved increasingly popular.

\section{Film Library}

There was another substantial increase, from 162 to 218 , in the bookings of the Society's much valued film library, and ro films were sent out specially to Ceylon to be shown as part of the $75^{\text {th }}$ jubilee celebrations of the Ceylon Wild Life Preservation Society. Three new short films, all of Australian wildlife (seals, penguins, mallee fowl) were acquired for the library, and at the end of the year the Society bought a copy of Eugen Schuhmacher's 'The Last of the Wild' as the centrepiece of its activities for European Conservation Year 1970.

\section{ORYX}

The usual three issues of ORYX were published, in May, September and December. High praise continues to be accorded to the journal under its present editorship from all parts of the world, and the Society can claim to possess the leading world journal for wildlife conservation.

\section{Christmas and other Sales}

Christmas card sales totalled 26,949 , nearly 7000 more than last year, and we are once more most indebted to David Shepherd for allowing us to use one of his fine elephant pictures. An innovation was a tray, in two sizes, with an Arabian oryx design specially painted for us by Keith Shackleton, to whom we are most grateful; 95 of these were sold. Once more we are grateful to many members who helped to swell our sales totals, and particularly to Mr E. G. Parkes, who sold $£ 75$ worth of cards and other goods, and Miss C. M. Moran who represented us at a Christmas card sale at Edinburgh, which realised $\ell_{24}$. The Society has also sold $\mathcal{E}_{14} \mathrm{O}$ worth of Red Data Books on behalf of IUCN.

\section{The Zoological Society of London}

The Society wishes once again to record its warmest thanks to the Zoological Society of London and its officers, for providing office accommodation and invaluable assistance of all kinds during the year. 


\section{The Auditors' Report}

To: The Council and Members of the

March 9 th 1970

Fauna Preservation Society

Accounts for the year ended 31st December 1969

We have completed the audit of the books and accounts of the Society for the year ended December 3Ist, 1969, and report thereon as follows:

\section{General Reserve Account}

This account has been formulated by amalgamating the General Reserve Fund, balance $£ 7,186$. I. 2 with the General Purposes Account Balance £323. II. 6 at Ist. January, 1969 .

The combined total of $£ 7,509$. 12.8 has been credited with $£ 57.10 .8$, profit on sales of investments, a legacy of $f_{1}, 000$ and $f_{125}$ transferred from the Life Membership Fund. From this total $\mathcal{E}_{548}$. 0 . Io, the excess of Expenditure over Income on the year's working, has been deducted leaving a balance of $£ 8,144.2 .6$.

\section{Life Membership Fund}

The balance standing to the credit of the Fund is now $\oint_{1} 0,337$. This is after crediting $£ 1,072$ in respect of Life Membership Subscriptions received during the year and transferring $\oint_{125}$ to the General Reserve Account which represents the value of subscriptions of those life members whose memberships ceased during the year.

\section{Revolving Fund}

Donations and other income received during the year totalled $£ 453$. I5. O which together with the balance at Ist. January I969 of $£ 5,876$. I4. 9 amounted to $£ 6,330.9 .9$. Grants of $£ 3,454$. I0. O were made on various projects, leaving a balance of $£ 2,875$. I9. 9 .

\section{Investments}

The total investments at 3Ist December, 1969, at cost amounted to $£_{14}, 262$. 16. 9 and the market value at that date was $£$ I7, I41. I8. 8, showing a net appreciation of $£ 2,879$. I. I I.

\section{Surplus}

The surplus of Assets over Liabilities at the end of the year amounted to $£ 18,483$. Io. 9, compared with $£ 17,037.6$. 4 at the end of the previous year.

W. B. KEEN \& CO Chartered Accountants 


\section{BALANCE SHEET}

\section{LIABILITIES}

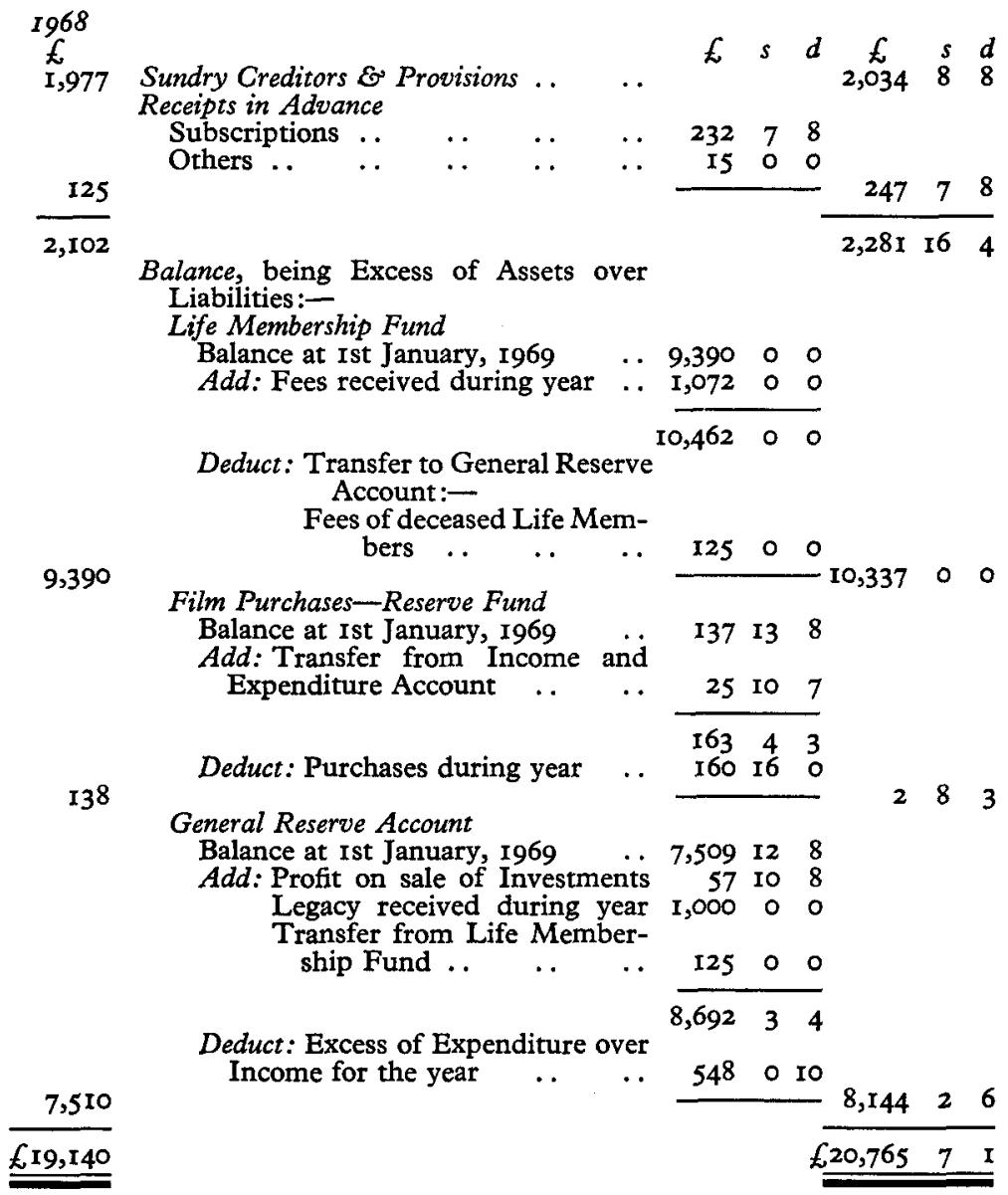




\section{1st DECEMBER, 1969}

\section{ASSETS}

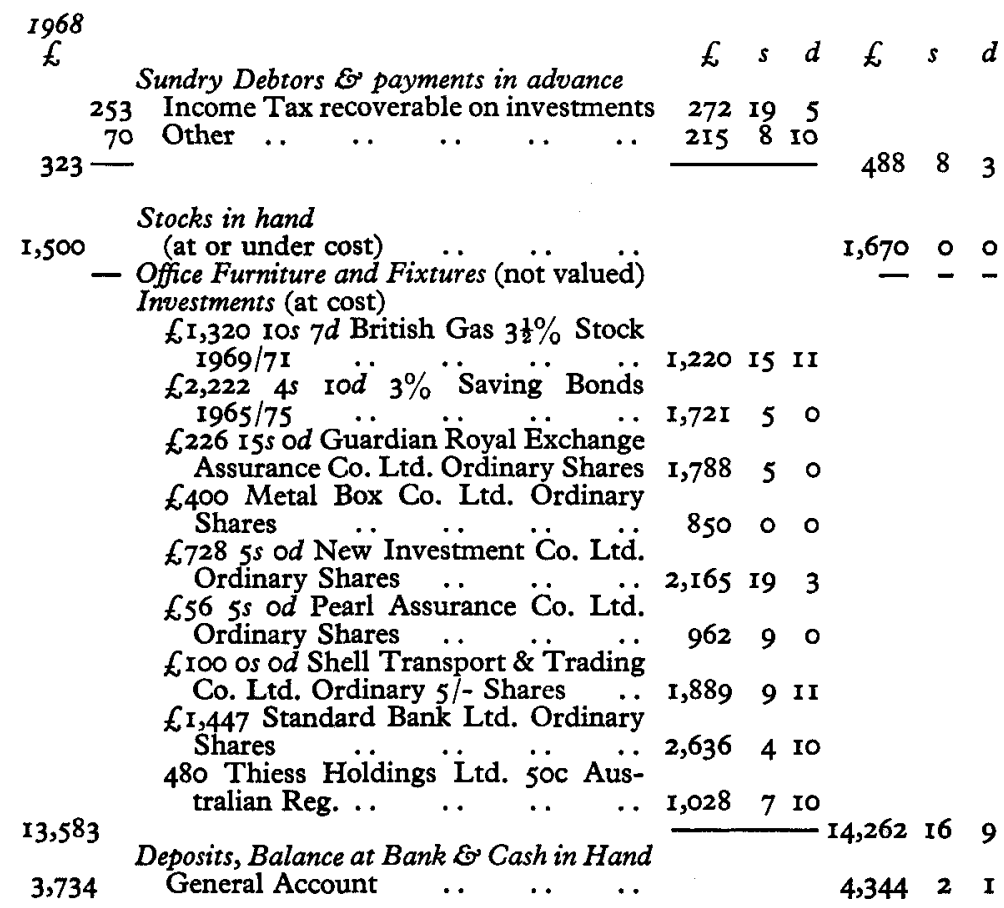




\section{INCOME AND EXPENDITURE ACCOUNT}

GENERAL PURPOSES

\section{EXPENDITURE}

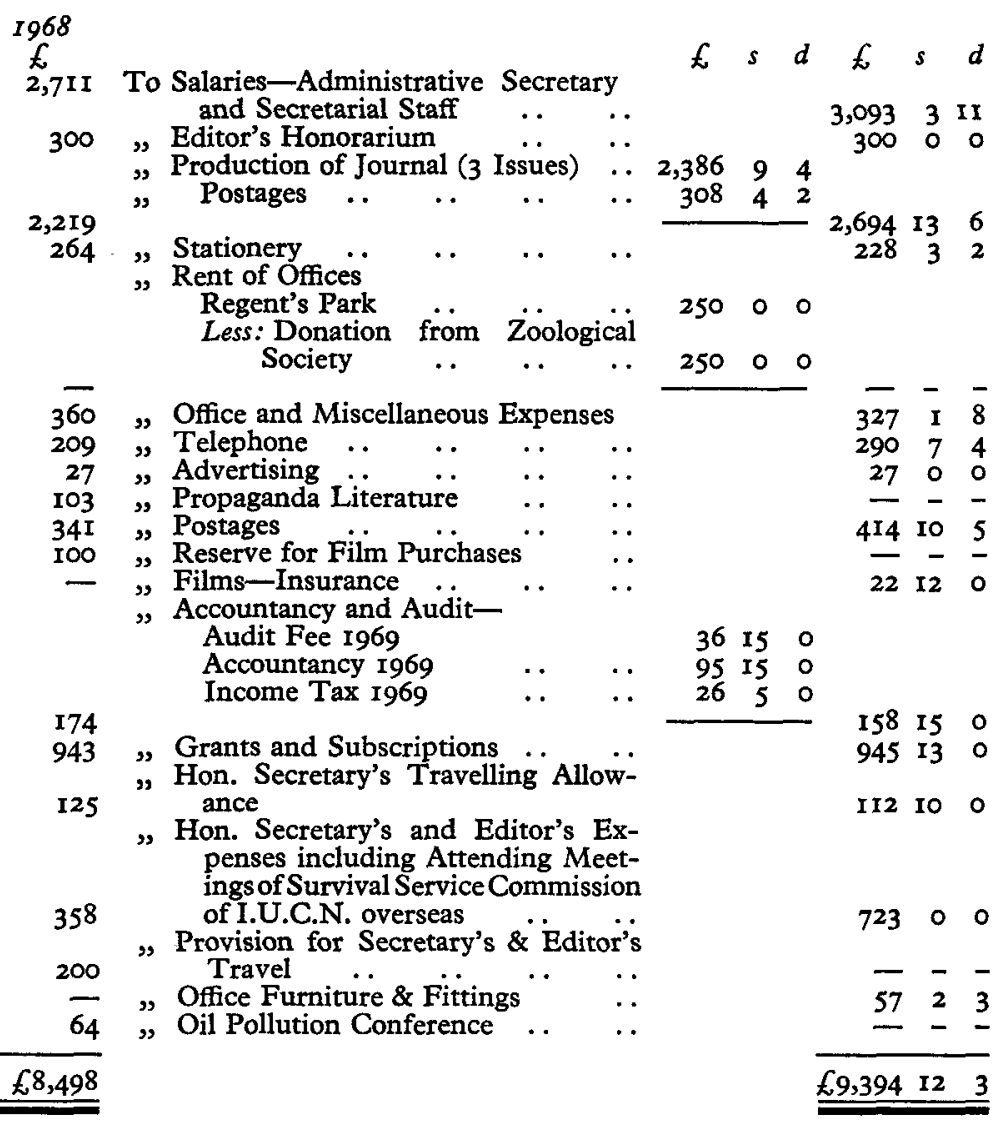




\section{for the year ended 31st DECEMBER, 1969}

\section{ACCOUNT}

INCOME

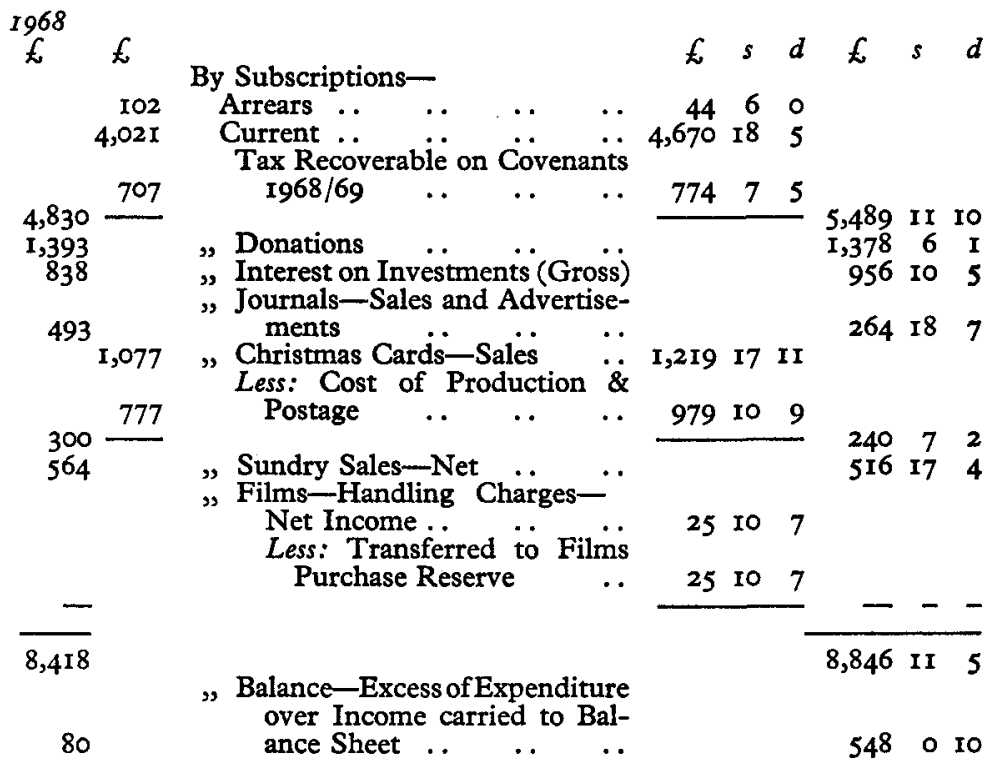

$£ 8,498$ 


\section{REVOLVING FUND ACCOUNT}

INCOME

\begin{tabular}{|c|c|c|c|c|c|c|c|c|c|c|}
\hline Balance at ist Janu & ary, & & $\cdots$ & $\cdots$ & $\cdots$ & & $s$ & $d$ & $\underset{5,876}{£}$ & $\begin{array}{l}s \\
I 4\end{array}$ \\
\hline Donations & $\ldots$ & . & . & . & $\cdots$ & 213 & 0 & 8 & & \\
\hline Bank Interest & $\therefore$ & $\ldots$ & . & .. & . & 240 & 14 & 4 & & \\
\hline & & & & & & & & & $4 J 3$ & 15 \\
\hline & & & & & & & & & 6,330 & 9 \\
\hline
\end{tabular}

GRANTS

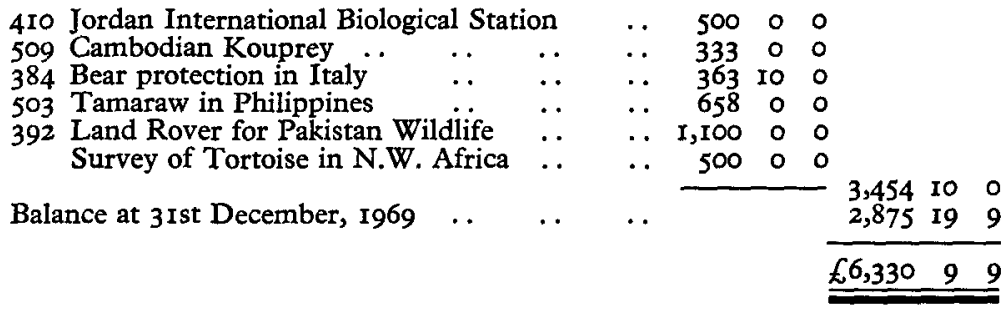

We have examined the above Balance Sheet and accompanying Income and Expenditure Account, and the Receipts and Payments Account relating to the Revolving Fund, with the books and Accounts of the Society and with the information and explanations supplied and certify them to be in accordance therewith. We have verified the Bank balance and the Investments of the various Funds.

Finsbury Circus House

Blomfield Street

London $\mathrm{EC} 2$

March 9th, 1970

W. B. KEEN \& CO

Chartered Accountants 